OPEN ACCESS

Edited by: Bart Devreese,

Ghent University, Belgium

Reviewed by:

Françoise Gosti,

Centre National de la Recherche

Scientifique, France

Isolde Francis,

California State University, Bakersfield,

USA

*Correspondence: Learn-Han Lee

lee.learn.han@monash.edu;

leelearnhan@yahoo.com Bey-Hing Goh

goh.bey.hing@monash.edu

Specialty section: This article was submitted to Antimicrobials, Resistance

and Chemotherapy,

a section of the journal

Frontiers in Microbiology

Received: 21 June 2016 Accepted: 03 January 2017 Published: 17 January 2017

Citation:

Law JW-F, Ser H-L, Khan TM,

Chuah L-H, Pusparajah P,

Chan K-G, Goh B-H and Lee L-H (2017) The Potential of Streptomyces as Biocontrol Agents against the Rice Blast Fungus, Magnaporthe oryzae

(Pyricularia oryzae).

Front. Microbiol. 8:3.

doi: 10.3389/fmicb.2017.00003

\section{The Potential of Streptomyces as Biocontrol Agents against the Rice Blast Fungus, Magnaporthe oryzae (Pyricularia oryzae)}

Jodi Woan-Fei Law' ${ }^{1}$, Hooi-Leng Ser', Tahir M. Khan ${ }^{1,2}$, Lay-Hong Chuah', Priyia Pusparajah ${ }^{3}$, Kok-Gan Chan ${ }^{4}$, Bey-Hing Goh ${ }^{1,5 *}$ and Learn-Han Lee ${ }^{1,5 *}$

${ }^{1}$ Novel Bacteria and Drug Discovery Research Group, School of Pharmacy, Monash University Malaysia, Bandar Sunway, Malaysia, ${ }^{2}$ Department of Pharmacy, Absyn University Peshawar, Peshawar, Pakistan, ${ }^{3}$ Biomedical Research Laboratory, Jeffrey Cheah School of Medicine and Health Sciences, Monash University Malaysia, Bandar Sunway, Malaysia, ${ }^{4}$ Division of Genetics and Molecular Biology, Faculty of Science, Institute of Biological Sciences, University of Malaya, Kuala Lumpur, Malaysia, ${ }^{5}$ Center of Health Outcomes Research and Therapeutic Safety, School of Pharmaceutical Sciences, University of Phayao, Phayao, Thailand

Rice is a staple food source for more than three billion people worldwide. However, rice is vulnerable to diseases, the most destructive among them being rice blast, which is caused by the fungus Magnaporthe oryzae (anamorph Pyricularia oryzae). This fungus attacks rice plants at all stages of development, causing annual losses of approximately $10-30 \%$ in various rice producing regions. Synthetic fungicides are often able to effectively control plant diseases, but some fungicides result in serious environmental and health problems. Therefore, there is growing interest in discovering and developing new, improved fungicides based on natural products as well as introducing alternative measures such as biocontrol agents to manage plant diseases. Streptomyces bacteria appear to be promising biocontrol agents against a wide range of phytopathogenic fungi, which is not surprising given their ability to produce various bioactive compounds. This review provides insight into the biocontrol potential of Streptomyces against the rice blast fungus, $M$. oryzae. The ability of various Streptomyces spp. to act as biocontrol agents of rice blast disease has been studied by researchers under both laboratory and greenhouse/growth chamber conditions. Laboratory studies have shown that Streptomyces exhibit inhibitory activity against $M$. oryzae. In greenhouse studies, infected rice seedlings treated with Streptomyces resulted in up to $88.3 \%$ disease reduction of rice blast. Studies clearly show that Streptomyces spp. have the potential to be used as highly effective biocontrol agents against rice blast disease; however, the efficacy of any biocontrol agent may be affected by several factors including environmental conditions and methods of application. In order to fully exploit their potential, further studies on the isolation, formulation and application methods of Streptomyces along with field experiments are required to establish them as effective biocontrol agents.

Keywords: Streptomyces, biocontrol, antifungal, rice, disease 


\section{INTRODUCTION}

Rice (Oryza sativa) is an important food crop and it is the staple diet of over three billion people around the world, particularly in Asia ${ }^{1}$ (Abdullah et al., 2006; Skamnioti and Gurr, 2009; HosseyniMoghaddam and Soltani, 2013). Nearly half of Asia’s population depends on rice as their main food source, making Asia the region with the highest rice consumption-more than $110 \mathrm{~kg}$ per capita annually (Hosseyni-Moghaddam and Soltani, 2013; Muthayya et al., 2014). Rice is grown in more than a 100 countries across a wide range of climatic conditions, ranging from rivers deltas to mountainous regions (Kyndt et al., 2014). Asian countries including China, India, Indonesia, Thailand, Philippines, Vietnam, Bangladesh, and Myanmar account for approximately $90 \%$ of the world's total rice production (Khush, 2005; Abdullah et al., 2006; Muthayya et al., 2014). The other rice-producing countries include Egypt, Brazil, sub-Saharan countries, and the USA (Kyndt et al., 2014). Wherever it is grown, however, rice is susceptible to diseases with far reaching economic implications. Infection with phytopathogenic fungi are among the most worrying of these diseases as it may result in significant crop yield losses, and additionally, some of the fungi produce compounds which are potentially toxic upon consumption (Chaiharn et al., 2009; Suprapta, 2012). For instance, several Fusarium, Aspergillus, and Penicillium species are capable of producing mycotoxins (e.g., aflatoxins, citrinin, fumonisins, ochratoxin $\mathrm{A}$, and zearalenone) which can be harmful to human beings if they are ingested via consumption of contaminated rice (Almaguer et al., 2012; Ferre, 2016). Given that the present methods of preventing rice diseases are not entirely satisfactory from several angles, it is imperative to seek new and effective methods of prevention in order to produce rice that is safe for consumption as well as to reduce crop yield losses.

Currently, Magnaporthe oryzae (anamorph Pyricularia oryzae) is regarded as one of the most important phytopathogenic fungi as it is the causal agent of rice blast - the most destructive disease of rice (Dean et al., 2012). M. oryzae B. Couch (anamorph Pyricularia oryzae Cav.), also known as Magnaporthe grisea (Hebert) Barr (anamorph Pyricularia grisea Sacc.), is a haploid filamentous ascomycete fungus (Bussaban et al., 2005). M. oryzae is defined as a new species distinct from $M$. grisea based on multilocus gene genealogy and laboratory mating experiments by Couch and Kohn (2002). On the basis of phylogenetic analysis, Magnaporthe is now separated into two distinct clades-one clade associated with Digitaria (crabgrass) maintains the name M. grisea, while the other clade associated with rice and other cultivated grasses was characterized as a novel species and given the name M. oryzae. Given the phylogenetic differences, however, there are no morphological differences between the isolates from these two clades. As a result, the names M. oryzae and M. grisea are still used interchangeably by scientists for the fungal isolates that infect rice (Besi et al., 2009; Wilson and Talbot, 2009).

Magnaporthe oryzae infects the aerial parts of the rice plant including leaves, nodes, stems, and panicles - at all stages of development (Wilson and Talbot, 2009). Infection results

\footnotetext{
${ }^{1}$ http://ricepedia.org/rice-as-food/the-global-staple-rice-consumers
}

in rice blast symptoms such as leaf blast, node blast, collar rot, neck rot, and panicle blast; this generally manifests as purplish/grayish/brownish/whitish spots or lesions as well as withering of leaves (Kato, 2001). This fungus was later discovered to also have the ability to infect the roots of the rice plant; and infection of the root may eventually spread to the aerial tissues, causing rice blast disease (Dufresne and Osbourn, 2001; Sesma and Osbourn, 2004). However, the exact nature and sequence of the process by which rice blast infects the roots of the rice plant has yet to be fully eludicated (Sesma and Osbourn, 2004). Rice blast disease has been reported in approximately 85 countries, mainly in Asia, Africa, and Latin America (Kato, 2001; Besi et al., 2009). Yield loss due to rice blast ranges from approximately 10$30 \%$ annually in the various rice producing countries and can reach up to $50 \%$ during disease epidemics (Skamnioti and Gurr, 2009; Ashkani et al., 2015).

Efforts have been made by researchers to identify and analyze the avirulence $(A V R)$ genes of $M$. oryzae. This would serve as the basis of understanding fungal mechanisms of pathogenesis and clarifying the mechanisms responsible for the coevolution of fungal effectors and their host targets (Yoshida et al., 2009). Besides this, development of cultivar-specific resistance involving gene-for-gene system can be achieved by conditioning resistance through high-yielding rice cultivars carrying single dominant disease resistance $(R)$ genes to a single corresponding dominant $A V R$ gene in a particular pathogen strain (Skamnioti and Gurr, 2009). To date, four AVR genes have been isolated from M. oryzae: $P W L 1$ and $P W L 2$ genes which encode Gly-rich hydrophobic proteins with secretion signal sequences, AVR-Pita gene which encodes a putative secreted protein with similarity to metalloproteases, and ACE1 gene which encodes a putative hybrid protein of a polyketide synthase and a peptide synthase (Skamnioti and Gurr, 2009; Yoshida et al., 2009). In contrast, more than 25 resistance $(R)$ genes encoding proteins that recognize M. oryzae AVRs have been mapped on the rice genome (Yoshida et al., 2009).

Besides breeding of cultivar-specific resistance, several control methods have been attempted to manage plant diseases. Among these, chemical control is the most commonly used method yielding effective management of plant diseases (Hirooka and Ishii, 2013). With reference to control of rice blast, chemical control involves the use of pesticides, specifically fungicides (Skamnioti and Gurr, 2009). A number of fungicides have been used against this disease, for instance, azoxystrobin, benomyl, carbendazim, carpropamid, dithiocarbamate, edifenphose, fenoxanil, tiadinil, tricyclazole, pyroquilon, probenazole, iprobenfos, isoprothiolane, metominostrobin, and propiconazole (Kato, 2001; Skamnioti and Gurr, 2009; Pooja and Katoch, 2014). Generally, the effectiveness of fungicides depends on several factors: the compound itself, the timing and method of application, the level of disease present, the efficiency of disease forecasting systems, and the rate of emergence of fungicide resistant strains (Kato, 2001; Skamnioti and Gurr, 2009). Although they are effective at controlling the fungal infections in rice, there are growing public concerns over the use of synthetic fungicides. Misuse and excessive use of synthetic pesticides (e.g., fungicides, insecticides, and herbicides) might 
cause environmental pollution, residual toxicity, development of pesticide resistance, reduce soil quality, and damage to natural ecosystems (Pimentel et al., 1991; Komárek et al., 2010; Suprapta, 2012; Yoon et al., 2013). Furthermore, human exposure to pesticides may cause poisoning and harmful sideeffects to organs and/or biological processes (Fattahi et al., 2015). Pesticide poisoning is a significant occupational health issue in developing countries, likely due to insufficient or poor occupational safety practices. Appropriate work practices are essential to ensure the safety of workers, particularly in the case of agricultural workers who are often exposed to pesticides during application and handling operations such as mixing, cleaning, loading spray equipment, and disposing of empty containers (Kesavachandran et al., 2009). Side effects and symptoms caused by exposure to pesticides have been reported in several developing countries. For instance, farmers in Vietnam reported symptoms such as skin irritation, headache, dizziness, eye irritation, shortness of breath, and acetyl cholinesterase inhibition due to the exposure to various pesticides during mixing and spraying (Dasgupta et al., 2007).

New and improved fungicides with minimal side effects are required in order to prevent these concerns. Nowadays, natural products which are safe for the environment and have low toxicity to living organisms are gaining interest as important sources for the development of fungicides, and these may serve as effective substitutes for synthetic fungicides (Martínez, 2012; Yoon et al., 2013). Moreover, another alternative approach to the use of fungicides is the use of microbial antagonists as biocontrol agents (Suprapta, 2012). Biocontrol agents are microorganisms that suppress plant pathogens (Pal and Gardener, 2006); they can achieve biological control through competition, antibiosis, and hyperparasitism (Montesinos, 2003). Biological control of plant diseases is known to be more cost effective, safe and environmentally friendly as compared to the use of fungicides. Streptomyces bacteria are among the microbial antagonists that have been exploited for the biological control of plant diseases. This review aims to encapsulate the current body of knowledge of the biocontrol potential of Streptomyces against the rice blast fungus, M. oryzae.

\section{Streptomyces spp. AS BIOCONTROL AGENTS AGAINST M. oryzae}

Streptomyces is the largest genus of the phylum Actinobacteria and was first proposed by Waksman and Henrici (1943). The genus Streptomyces consists of a group of Gram-positive, aerobic, non-motile, catalase positive, and non-acid-fast bacteria with a filamentous form that resembles fungi (Flärdh and Buttner, 2009; Hasani et al., 2014). Currently, over 700 species of Streptomyces have been identified ${ }^{2}$ and these bacteria have relatively large genomes of approximately 8-9 Mbp in size with a high GC content of more than 70\% (Wu et al., 2005; Hasani et al., 2014; Ser et al., 2015c).

${ }^{2} \mathrm{http}: / /$ www.bacterio.net/
The members of Streptomyces are well-known for their ability to produce a variety of bioactive compounds with different bioactivities such as antibacterial (Schumacher et al., 2003; Ramesh and Mathivanan, 2009; de Lima Procópio et al., 2012; Kumar et al., 2014; Lee et al., 2014a,b; Ser et al., 2016a), antifungal (Lam, 2006), antiviral (Ara et al., 2014), immunosuppressive (Kino et al., 1987), anticancer, and antioxidant properties (Ser et al., 2015a; Tan et al., 2015, 2016). These bioactive compounds have important applications in various fields. For example, approximately $75 \%$ of commercially useful antibiotics were derived from the genus Streptomyces and they are thus the primary antibiotic-producing organisms exploited by the pharmaceutical industry (Pelaez, 2006; Lee et al., 2014b; Kashif et al., 2016). Streptomyces strains also have important applications in the agricultural field through their biological control potential against phytopathogens, particularly phytopathogenic fungi (Gonzalez-Franco and Robles-Hernandez, 2009). In line with this, research on the biological control of rice blast disease using different Streptomyces species has been conducted under laboratory conditions, as well as in greenhouse or growth chamber conditions.

\section{In vitro Experiments}

Studies have reported in vitro antagonism of different Streptomyces spp. against $M$. oryzae which were tested using the dual culture method. Dual culture method has been widely used for preliminary screening of biocontrol agents including fungi and bacteria. This method allows the biocontrol agent and pathogen to interact on a solid medium in a Petri dish, under optimal conditions for both organisms. The degree of inhibition is recorded by observing the inhibition zone produced or the overgrowth of the pathogen by the biocontrol agent (Desai et al., 2002).

In a study conducted by Ningthoujam et al. (2009), S. vinaceusdrappus isolated from Loktak lake sediment was first reported to exhibit antagonistic activity against $M$. oryzae (P. oryzae MTCC 1477). S. vinaceusdrappus also showed maximal antagonistic activity against most of the rice fungal pathogens tested, which include Curvularia oryzae, Bipolaris oryzae, and Fusarium oxysporum. S. vinaceusdrappus inhibited the mycelial growth of $P$. oryzae by $53.5 \%$, which was relatively good since more than $50 \%$ of the mycelial growth was inhibited. Boukaew and Prasertsan (2014) reported that Streptomyces philanthi RM-1-138 isolated from rhizosphere soil of chili pepper in Southern Thailand exhibited significant antifungal activity against $M$. oryzae (P. oryzae PTRRC-18), with $88.73 \%$ inhibition of mycelial growth of the rice blast fungus. This suggests that S. philanthi RM-1-138 has greater inhibition against the rice blast fungus as compared to $S$. vinaceusdrappus.

The in vitro assay conducted by Li et al. (2011) showed that Streptomyces globisporus JK-1 demonstrated the most pronounced inhibitory effects against $M$. oryzae as compared to other phytopathogenic fungi tested in the study. S. globisporus JK-1 inhibited mycelial growth of $M$. oryzae with an inhibition zone of $15 \mathrm{~mm}$ out of $35 \mathrm{~mm}$. A study also showed that endophytic Streptomyces from rice cultivars in China demonstrate antagonism against rice fungal pathogens, 
particularly $54.5 \%$ of Streptomyces griseofuscus and $21.8 \%$ of Streptomyces hygroscopicus were the most active among the studied population of antagonistic endophytic Streptomyces which exhibited strong antagonism against M. oryzae (Tian et al., 2004). Streptomyces sindeneusis isolate 263 and Streptomyces isolate 339 obtained from agricultural soils of Kerman in Iran were also found to inhibit M. oryzae (Zarandi et al., 2009, 2013). In addition, Khalil et al. (2014) reported that Streptomyces flavotricini isolated from Egyptian rice field soils showed the strongest antifungal activity against $M$. oryzae; the antifungal compound produced by $S$. flavotricini was successfully purified and identified as dihydroxy viridiofungin $\left(\mathrm{C}_{37} \mathrm{H}_{58} \mathrm{~N}_{2} \mathrm{O}_{10}\right)$.

Based on these findings, S. vinaceusdrappus, S. philanthi RM1-138, S. griseofuscus, S. hygroscopicus, Streptomyces isolate 339, and $S$. flavotricini are potential candidates for use as biocontrol agents against rice blast as they possess inhibitory activity against $M$. oryzae (Table 1). Based on the percentage of mycelial growth inhibition, S. philanthi RM-1-138 appears to be one of the most promising agents for the inhibition of M. oryzae. However, studies involving greenhouse or field experiments are still required to more definitively evaluate the biocontrol potential of these Streptomyces spp. against M. oryzae.

\section{Greenhouse/Growth Chamber Experiments}

The limitation of laboratory experiments is that they only prove the antagonistic activity of Streptomyces spp. against $M$. oryzae under certain conditions. The antagonism exhibited by Streptomyces in laboratory experiments might not necessarily reflect antagonism under greenhouse or field experiments. Greenhouse or growth chamber experiments are conducted for the purpose of further evaluating the efficacy of Streptomyces strains as biocontrol agents. For S. sindeneusis isolate 263 and S. globisporus JK-1, studies on their biocontrol potential against the fungus under greenhouse conditions were conducted by Zarandi et al. (2009) and Li et al. (2011) respectively. Zarandi et al. (2009) reported that typical blast symptoms were observed when rice plants at the three leaf-stage of vegetative phase were treated with $M$. oryzae. The percentage of diseased leaf area was evaluated according to the method developed by the International Rice Research Institute (IRRI). It was found that the rice plants receiving treatment with $S$. sindeneusis isolate 263 showed significantly reduced lesion development. The diseased leaf area was $8 \%$ for rice plants treated with $M$. oryzae alone, while it was only $0.5 \%$ for rice plants treated with $S$. sindeneusis isolate 263 in combination with $M$. oryzae. This result indicates that $S$. sindeneusis isolate 263 acted as an antagonist.

Li et al. (2011) compared the control of the rice blast using Streptomyces and fungicide by infecting rice plants at the five leaf-stage during the vegetative growth phase with $M$. oryzae, followed by treatment with culture filtrates of S. globisporus JK-1 and tricyclazole respectively. Tricyclazole is one of the commonly used fungicides for the control of rice blast disease with several advantages over other fungicides, for instance, it is systemic in rice for blast control and has long residual effectiveness (Froyd et al., 1976). The results showed that control efficacy for S. globisporus JK-1 treatment was $88.3 \%$ and for tricyclazole was $79.4 \%$, compared to the inoculated control. This suggests that S. globisporus is as efficient and possibly even superior to tricyclazole, with the additional benefits of biocontrol agents as compared to synthetic agents described earlier.

Additionally, a novel Streptomyces strain, BG2-53, with 96\% homology to $S$. lipmanii based on analysis of $16 \mathrm{~S}$ rDNA sequences, exhibited potent antifungal activity against $M$. oryzae under growth chamber conditions (Lee et al., 2002). The strain showed the highest degree of fungal control in comparison to fungicides such as Blasticidin-S and Tricyclazole. However, the evaluation on the extent of rice disease infection was solely based on visual estimation, unlike other studies where the Standard Evaluation System of IRRI was applied.

Overall, the results of greenhouse and growth chamber experiments strongly suggest that several Streptomyces spp. possess antagonistic activities against $M$. oryzae, and therefore have the potential to effectively control rice blast. Field experiments are still required to more definitively estimate the efficacy of Streptomyces spp. as biocontrol agents under real life conditions as environmental factors greatly affect their performance.

\section{Bioactive Compounds from Streptomyces spp. with Antifungal Activity against $M$. oryzae}

The suppression of rice blast in the greenhouse by certain Streptomyces might indicate the presence of bioactive compound(s) with antifungal activity against $M$. oryzae in the culture filtrates. Streptomyces are prolific producers of bioactive compounds. Some well-known antibiotics produced by Streptomyces have been used as fungicides for the control of rice blast, for instance, Blasticidin-S and Kasugamycin. Blasticidin-S, isolated from $S$. griseochromogenes was the first antibiotic commercially introduced for the control of rice blast in Japan (Fukunaga et al., 1955; Takeuchi et al., 1958; Tapadar and Jha, 2013). Kasugamycin was discovered soon after; it was first isolated from S. kasugaensis by Umezawa et al. (1965). Kasugamycin has been safely used to protect rice plants against blast disease; it has relatively low mammalian toxicity and no phytotoxicity toward rice plants and most crops (Yamaguchi, 1982; Copping and Duke, 2007). Recently, the significance of Blasticidin-S as a fungicide has decreased as it has been replaced by new pathogen-specific fungicides with lower toxicity (Copping and Duke, 2007). Kasugamycin is currently still on the market and is sold in several different formulations such as wettable powder, granule, and soluble liquid under the trade names Kasumin and Kasumin-Bordeaux from Hokko Chemical Industry, Co., Ltd (Copping and Duke, 2007; Hokko, 2015).

Several studies have performed testing of the various compounds produced by Streptomyces on M. oryzae. These studies have shown that several compounds produced by Streptomyces spp. exhibited antifungal activity against $M$. oryzae (Appendix 1). The antibiotic Oligomycin A was first isolated from $S$. diastatochromogenes and was found to be active against several other phytopathogenic fungi in addition to M. oryzae such 


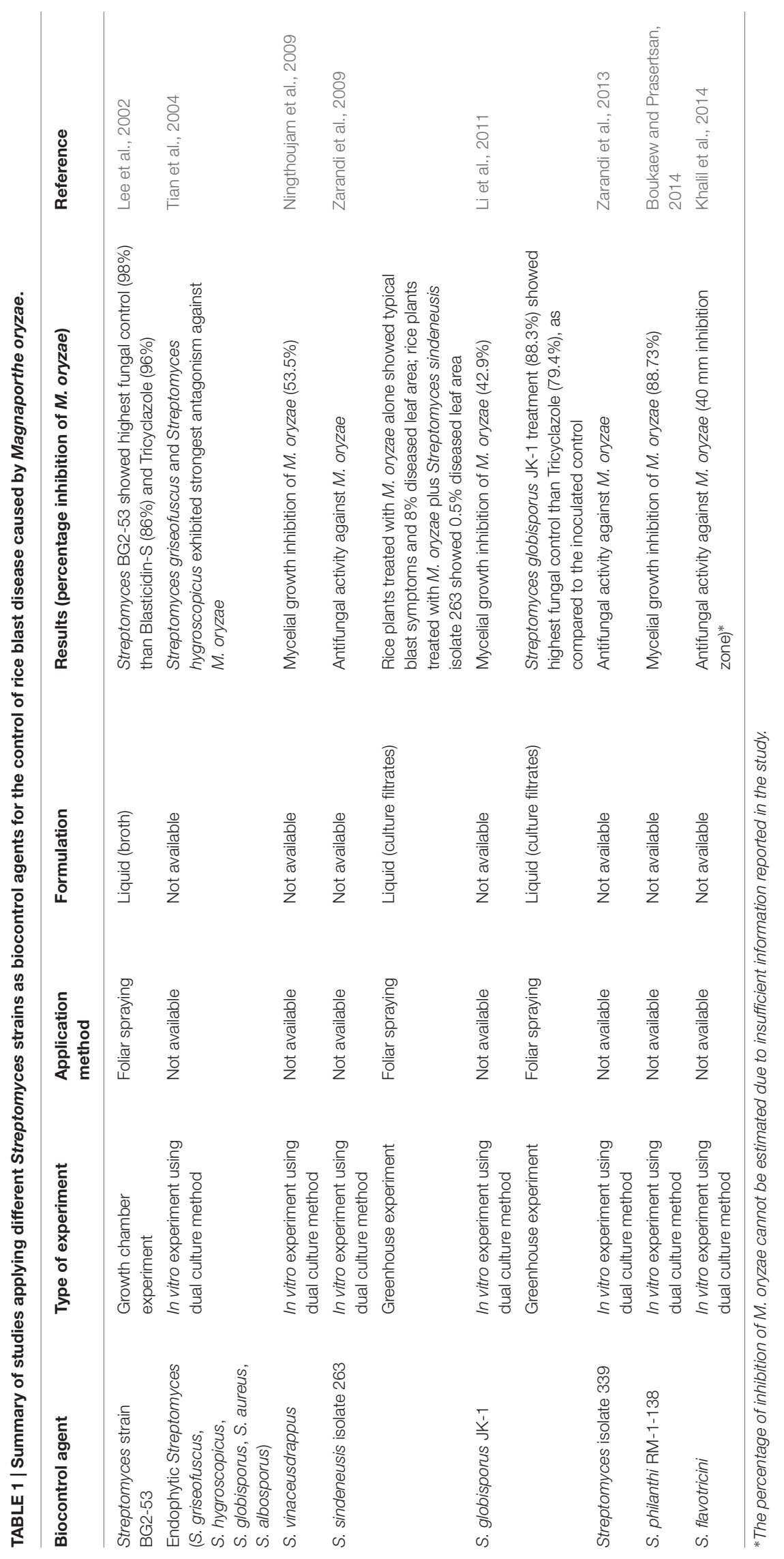


as Botrytis cinerea, Cladosporium cucumerinum, Colletotrichum lagenarium, Phytophthora capsici, Alternaria alternata, and Aspergillus niger (Smith et al., 1954; Kim et al., 1999; Yang et al., 2010). Oligomycin A's ability to control the development of rice blast was evaluated in the greenhouse and the results showed that rice plants treated with Oligomycin A $(50 \mu \mathrm{g} / \mathrm{mL})$ had reduced lesions. When the concentration of Oligomycin A was increased up to $500 \mu \mathrm{g} / \mathrm{mL}$, the rice plants did not show any rice blast disease symptoms (Kim et al., 1999).

Rapamycin-also known as Sirolimus-was initially isolated from S. hygroscopicus (Sehgal et al., 1975; Sehgal, 1998). Rapamycin is a potent antifungal agent found to be effective against Candida albicans, Microsporum gypseum, and Trichophyton granulosum (Sehgal et al., 1975). Bastidas et al. (2012) reported that Rapamycin inhibited the growth of Mucor circinelloides and Rhizopus oryzae, both of which are post-harvest fruit pathogens (Johnson et al., 1990; Kwon et al., 2011).

Other compounds such as Pyrroles (Pyrrolo[1,2-a] pyrazine1,4-dione, hexahydro-) are commonly found in various Streptomyces species (Robertson and Stevens, 2014; Ser et al., 2015b, 2016b,c; Tan et al., 2015; Awla et al., 2016). Furthermore, Pyrrolo[1,2-a] pyrazine-1,4-dione, hexahydro-3-(phenylmethyl) was found to be able to protect plants from phytopathogenic fungi (Zhou et al., 2015).

Bioactive compounds derived from Streptomyces can be used for the management of fungal plant diseases as an alternative to synthetic fungicides (Prabavathy et al., 2006). These natural compounds are biologically synthesized and often biodegradable. Thus, they may be useful for the development of agricultural fungicides that are more pathogen-specific with minimal sideeffects toward the environment (Varma and Dubey, 1999; Prabavathy et al., 2006). In order to formally establish any organism as a commercially viable biocontrol agent, studies involving the application of the microbial antagonist in question on a certain plant for the control of a particular pathogen are required to investigate their effectiveness. Although it is too early to draw any definite conclusions, the Streptomyces spp. listed in Table 1 could be considered potential biocontrol agents, as they are capable of producing compounds with antifungal activity against M. oryzae.

\section{ANTAGONISTIC MECHANISMS OF BIOCONTROL AGENTS}

It is known that antagonistic activities of bacteria against fungal pathogens can be achieved through three main mechanisms: competition for nutrients and space, antibiosis, and parasitism (Gonzalez-Franco and Robles-Hernandez, 2009; Boukaew and Prasertsan, 2014). The advantages of Streptomyces spp. include their ability to colonize plant root surfaces, survive in various types of soil and also produce spores which allow them to survive longer and in various extreme conditions (GonzalezFranco and Robles-Hernandez, 2009; Ningthoujam et al., 2009). Antibiosis happens when the antagonist present in the plant produces metabolites such as antibiotics or antifungals which can inhibit or kill the pathogen. Streptomyces spp. used as biocontrol agents produced antibiotics such as geldanamycin and nigericin for the control of plant diseases, which were proven by the presence of antibiotics in soil (Rothrock and Gottlieb, 1984; Trejo-Estrada et al., 1998). Likewise, hyperparasitism may occur due to the release of extracellular lytic enzymes such as chitinases and glucanases from the biocontrol agent (GonzalezFranco and Robles-Hernandez, 2009; Palaniyandi et al., 2013). It has also been shown that Streptomyces spp. are capable of producing chitinases and glucanases which play important roles in destruction of fungal cell walls (Mahadevan and Crawford, 1997; El-Tarabily et al., 2000; Gonzalez-Franco and RoblesHernandez, 2009). The colonization ability and competitive traits of Streptomyces could result in successful competition against phytopathogenic fungi and suppression of their growth. It can be presumed that the suppression of rice blast by Streptomyces spp. might be due to these mechanisms, but further studies are required to provide evidence regarding the actual biocontrol mechanisms of Streptomyces against M. oryzae.

\section{CHALLENGES FOR SUCCESSFUL APPLICATION OF BIOCONTROL AGENTS}

One of the major challenges encountered during the selection of biocontrol agents is that biocontrol agents that appear efficacious based on in vitro experiments might not be effective in controlling plant diseases in greenhouse or field conditions. The efficacy of biocontrol agents is affected by organic matter, $\mathrm{pH}$, nutrient level, and moisture level of the soil. Owing to the variations in environmental conditions in different locations, biocontrol agents that perform well in in vitro conditions might fail in greenhouse or field experiments. Therefore, the environmental factors at the location where biocontrol agents will be applied should be taken into consideration during the selection of appropriate biocontrol agents. Ideally, the biocontrol agents should be isolated from and applied to locations with similar environmental factors in order to achieve successful biological control (Suprapta, 2012). Furthermore, the formulation (e.g., powder, liquid, or granule) and the method of application of biocontrol agents such as soil inoculation, seed inoculation, and vegetative part inoculation should be examined (Figure 1) as they are important in determining the outcomes of field experiments (Ou, 1980; Dubey, 1993). Soil inoculation involves mixing of the biocontrol agent with soil or spreading the biocontrol agent in sowing furrows by drip systems (Vasudevan et al., 2002). Seed inoculation involves dipping seeds in a culture of the biocontrol agent or mixing the seeds with the inoculant using appropriate wetting agents (Dubey, 1993; Vasudevan et al., 2002; Yang et al., 2008). Vegetative part inoculation involves aerial/foliar spraying of the biocontrol agent or seedling treatment by dipping the roots of the seedlings into a solution containing the biocontrol agent prior to transplantation (Vasudevan et al., 2002; Gopalakrishnan et al., 2014) (Figure 1). The appropriate application method is likely to contribute significantly to the success of the biocontrol agents in the field trials (Suprapta, 2012). 


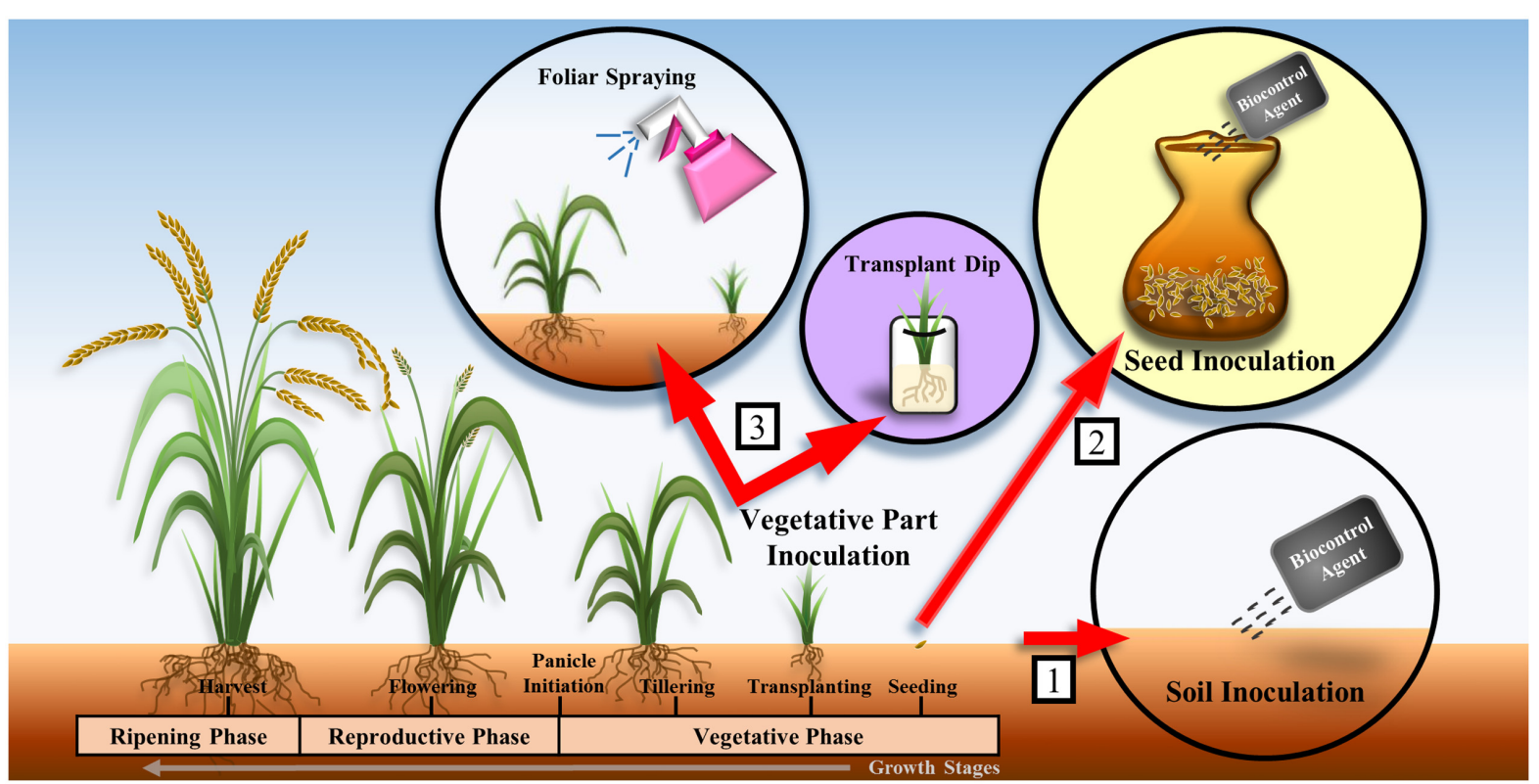

FIGURE 1 | Methods of application of biocontrol agents on rice plants: (1) soil inoculation, (2) seed inoculation, and (3) vegetative part inoculation. Many studies involved the application of biocontrol agents on rice plant during the vegetative phase (Yang et al., 2008; Laborte et al., 2012; Gopalakrishnan et al., 2014).

\section{EXAMPLES OF COMMERCIAL Streptomyces BIOCONTROL AGENTS}

Some Streptomyces spp. have been successfully developed into commercial biocontrol agents and tested for the control of other plant diseases. For example, Streptomyces griseoviridis strain K61 (Mycostop $^{\circledR}$ ), which has been tested for the control of Ceratocystis radicicola that causes black scorch on date palm and soilborne pathogens of tomato such as Fusarium oxysporum f.sp. lycopersici and Verticillium dahliae (Suleman et al., 2002; Minuto et al., 2006). Other commercial Streptomyces biocontrol agents include S. lydicus WYEC108 (Actinovate ${ }^{\circledR}$, Micro108 $^{\circledR}$, Action Iron ${ }^{\circledR}$ ), and S. saraceticus KH400 (YAN TEN S. saraceticus) (Elliott et al., 2009; Palaniyandi et al., 2013). Biocontrol agents are relatively safe toward humans as no adverse effects in users and other workers have been reported following exposure to these commercial products (Pest Management Regulatory Agency, 2003; U. S. Environmental Protection Agency, 2005). However, hypersensitivity may occur in certain individuals on exposure to biological dust produced during handling of S. griseoviridis strain K61 (Mycostop ${ }^{\circledR}$ ) dry end-product (Pest Management Regulatory Agency, 2003). Hence, wearing appropriate safety equipment is required when handling these agents. With reference to the control of rice blast disease, however, commercial Streptomyces biocontrol agents have yet to be developed.

\section{CONCLUSION}

Rice blast, the result of infection by $M$. oryzae, is the most destructive disease of rice, leading to crop yield losses and economic damage. While chemical control has been the mainstay of controlling this infection, biological control has now been introduced as an alternative for the management of rice blast disease. Biological control of plant diseases is typically inexpensive, long lasting, and safe toward the environment and living organisms; however, biological control can be a slow process and the search for suitable biocontrol agents requires considerable time and effort. Streptomyces spp. certainly demonstrate the potential to be developed as biocontrol agents due to their various beneficial properties. Based on current research findings, S. vinaceusdrappus, S. philanthi RM-1-138, S. griseofuscus, S. hygroscopicus, Streptomyces isolate 339, and $S$. flavotricini showed antifungal activity against $M$. oryzae under in vitro conditions. S. sindeneusis isolate 263 and S. globisporus JK-1 demonstrated in vitro antifungal activity against $M$. oryzae as well as successful biocontrol of rice blast in greenhouse experiments. Streptomyces strain BG2-53, which appears to be a novel strain, showed antifungal activity against $M$. oryzae under growth chamber conditions. These Streptomyces spp. possess antagonistic activities against $M$. oryzae, with S. globisporus JK-1 showing high control efficacy of up to $88.3 \%$. Furthermore, studies have revealed that Streptomyces produces various compounds with antifungal activity against $M$. oryzae. Therefore, they are excellent candidates as biocontrol agents for the biological control of this devastating rice blast disease. In order to establish Streptomyces as biocontrol agents, more field experiments should be conducted to determine their control efficacy under different environmental conditions. Additionally, more work is needed to optimize isolation, formulation and application methods of Streptomyces in order to fully maximize their potential as effective agents to control rice blast. 


\section{AUTHOR CONTRIBUTIONS}

The literature review and manuscript writing were performed by JL and H-LS, while TK, L-HC, PP, K-GC, B-HG, and L-HL provided vital guidance and insight for the writing. The research topic was conceptualized by L-HL and B-HG.

\section{ACKNOWLEDGMENTS}

This work was supported by PVC Award Grant (Project No. PVC-ECR-2016), External Industry Grant (Biotek Abadi - Vote

\section{REFERENCES}

Abdullah, A. B., Ito, S., and Adhana, K. (2006). "Estimate of rice consumption in Asian countries and the world towards 2050," in Proceedings for Workshop and Conference on Rice in the World at Stake 2, Chiang Mai, 28-43.

Almaguer, M., Rojas, T. I., Rodríguez-Rajo, F. J., and Aira, M. J. (2012). Airborne fungal succession in a rice field of Cuba. Eur. J. Plant Pathol. 133, 473-482. doi: 10.1007/s10658-011-9921-0

Ara, I., Bukhari, N. A., Aref, N., Shinwari, M. M., and Bakir, M. (2014). Antiviral activities of streptomycetes against tobacco mosaic virus (TMV) in Datura plant: evaluation of different organic compounds in their metabolites. Afr. J. Biotechnol. 11, 2130-2138. doi: 10.5897/AJB11.3388

Ashkani, S., Yusop, M. R., Shabanimofrad, M., Harun, A. R., Sahebi, M., and Latif, M. A. (2015). Genetic analysis of resistance to rice blast: a study on the inheritance of resistance to the blast disease pathogen in an F3 population of rice. J. Phytopathol. 163, 300-309. doi: 10.1111/jph.12323

Awla, H. K., Kadir, J., Othman, R., Rashid, T. S., and Wong, M.-Y. (2016). Bioactive compounds produced by Streptomyces sp. isolate UPMRS4 and antifungal activity against Pyricularia oryzae. Am. J. Plant Sci. 7, 1077-1085. doi: 10.4236/ ajps.2016.77103

Bastidas, R. J., Shertz, C. A., Lee, S. C., Heitman, J., and Cardenas, M. E. (2012). Rapamycin exerts antifungal activity in vitro and in vivo against Mucor circinelloides via FKBP12-dependent inhibition of Tor. Eukaryot. cell 11, 270-281. doi: 10.1128/EC.05284-11

Besi, M. I., Tucker, S. L., and Sesma, A. (2009). "Magnaporthe and its relatives", in Encyclopedia of Life Sciences (ELS), (Chichester: John Wiley \& Sons, Ltd), 1-9.

Boukaew, S., and Prasertsan, P. (2014). Suppression of rice sheath blight disease using a heat stable culture filtrate from Streptomyces philanthi RM-1-138. Crop Protect. 61, 1-10. doi: 10.1016/j.cropro.2014.02.012

Bussaban, B., Lumyong, S., Lumyong, P., Seelanan, T., Park, D., Mckenzie, E., et al (2005). Molecular and morphological characterization of Pyricularia and allied genera. Mycologia 97, 1002-1011. doi: 10.3852/mycologia.97.5.1002

Chaiharn, M., Chunhaleuchanon, S., and Lumyong, S. (2009). Screening siderophore producing bacteria as potential biological control agent for fungal rice pathogens in Thailand. World J. Microbiol. Biotechnol. 25, 1919-1928. doi: 10.1007/s11274-009-0090-7

Copping, L. G., and Duke, S. O. (2007). Natural products that have been used commercially as crop protection agents. Pest Manag. Sci. 63, 524-554. doi: $10.1002 /$ ps. 1378

Couch, B. C., and Kohn, L. M. (2002). A multilocus gene genealogy concordant with host preference indicates segregation of a new species, Magnaporthe oryzae, from M. grisea. Mycologia 94, 683-693. doi: 10.2307/3761719

Dasgupta, S., Meisner, C., Wheeler, D., Xuyen, K., and Lam, N. T. (2007). Pesticide poisoning of farm workers-implications of blood test results from Vietnam. Int. J. Hyg. Environ. Health 210, 121-132. doi: 10.1016/j.ijheh.2006.08.006

de Lima Procópio, R. E., Da Silva, I. R., Martins, M. K., De Azevedo, J. L., and De Araújo, J. M. (2012). Antibiotics produced by Streptomyces. Braz. J. Infect. Dis. 16, 466-471. doi: 10.1016/j.bjid.2012.08.014

Dean, R., Van Kan, J. A., Pretorius, Z. A., Hammond-Kosack, K. E., Di Pietro, A., Spanu, P. D., et al. (2012). The Top 10 fungal pathogens in molecular plant pathology. Mol. Plant Pathol. 13, 414-430. doi: 10.1111/j.1364-3703.2011. 00783.x
No. GBA-808813), MOSTI eScience funds (Project No. 06-02-10SF0300) awarded to L-HL, and University of Malaya for High Impact Research Grant (UM-MOHE HIR Nature Microbiome Grant No. H-50001-A000027 and No. A000001-50001) awarded to K-GC.

\section{SUPPLEMENTARY MATERIAL}

The Supplementary Material for this article can be found online at: http://journal.frontiersin.org/article/10.3389/fmicb. 2017.00003/full\#supplementary-material

Desai, S., Reddy, M. S., and Kloepper, J. W. (2002). "Chapter 17: comprehensive testing of biocontrol agents," in Biological Control of Crop Diseases, ed. S. S. Gnanamanickam (New York, NY: Marcel Dekker), 387-420.

Dubey, R. C. (ed.). (1993). "Chapter 21: biopesticides (biological control of plant pathogens, pests and weeds," in A Textbook of Biotechnology (India: S. Chan Publishing), 457-475.

Dufresne, M., and Osbourn, A. E. (2001). Definition of tissue-specific and general requirements for plant infection in a phytopathogenic fungus Mol. Plant Microbe Int. 14, 300-307. doi: 10.1094/MPMI.2001.14 3.300

Elliott, M., Shamoun, S., Sumampong, G., James, D., Masri, S., and Varga, A. (2009). Evaluation of several commercial biocontrol products on European and north American populations of Phytophthora ramorum. Biocontrol Sci. Technol. 19, 1007-1021. doi: 10.1080/09583150903243870

El-Tarabily, K., Soliman, M., Nassar, A., Al-Hassani, H., Sivasithamparam, K., Mckenna, F., et al. (2000). Biological control of Sclerotinia minor using a chitinolytic bacterium and actinomycetes. Plant Pathol. 49, 573-583. doi: 10. 1046/j.1365-3059.2000.00494.x

Fattahi, E., Mousavi Moghadam, M., and Khanbabaei, R. (2015). The effect of fricyclazole on testosterone changes and testicular structure in mice. J. Babol. Univ. Med. Sci. 17, 43-49.

Ferre, F. S. (2016). Worldwide occurrence of mycotoxins in rice. Food Control 62 291-298. doi: 10.1016/j.foodcont.2015.10.051

Flärdh, K., and Buttner, M. J. (2009). Streptomyces morphogenetics: dissecting differentiation in a filamentous bacterium. Nat. Rev. Microbiol. 7, 36-49. doi: $10.1038 /$ nrmicro1968

Froyd, J., Paget, C., Guse, L., Dreikorn, B., and Pafford, J. (1976). Tricyclazole: a new systemic fungicide for control of Pyricularia oryzae on rice. Phytopathology 66, 1135-1139. doi: 10.1094/Phyto-66-1135

Fukunaga, K., Misato, T., Ishii, I., and Asakawa, M. (1955). Blasticidin, a new anti-phytopathogenic fungal substance. Part I. J. Agric. Chem. Soc. Japan 19, 181-188. doi: 10.1271/bbb1924.19.181

Gonzalez-Franco, C., and Robles-Hernandez, R. (2009). Actinomycetes as biological control agents of phytopathogenic fungi. Tecnociencia Chihuahua 3, 64-73.

Gopalakrishnan, S., Vadlamudi, S., Bandikinda, P., Sathya, A., Vijayabharathi, R., Rupela, O., et al. (2014). Evaluation of Streptomyces strains isolated from herbal vermicompost for their plant growth-promotion traits in rice. Microbiol. Res. 169, 40-48. doi: 10.1139/cjm-2013-0287

Hasani, A., Kariminik, A., and Issazadeh, K. (2014). Streptomycetes: characteristics and their antimicrobial activities. Int. J. Adv. Biol. Biomed. Res. 2, 63-75.

Hirooka, T., and Ishii, H. (2013). Chemical control of plant diseases. J. Gen. Plant Pathol. 79, 390-401. doi: 10.1007/s10327-013-0470-6

Hokko (2015). Company Information and Market Report of Agrochemicals in Japan. Available at: https://www.hokkochem.co.jp/wp-content/uploads/2015. pdf (accessed June19, 2016).

Hosseyni-Moghaddam, M., and Soltani, J. (2013). An investigation on the effects of photoperiod, aging and culture media onvegetative growth and sporulation of rice blast pathogen pyricularia oryzae. Prog. Biol. Sci. 3, 135-143.

Iwasa, T., Kishi, T., Matsuura, K., and Wakae, O. (1977). Streptomyces novoguineensis sp. nov., an amipurimycin producer, and antimicrobial activity of amipurimycin. J. Ant. 30, 1-10. doi: 10.7164/antibiotics.30.1 
Johnson, G., Sangchote, S., and Cooke, A. (1990). Control of stem end rot (Dothiorella dominicana) and other postharvest diseases of mangoes (cv. Kensington Pride) during short-and long-term storage. Trop. Agric. 67, 183-187.

Kashif, M. D., Kumar, V., Kalpana, V. N., and Devi Rajeswari, V. (2016). Phylogenetic diversity and biological activity of actinomycetes isolated from Gulf of Mannar, Tamil Nadu, India. Pharm. Lett. 8, 16-24.

Kato, H. (2001). Rice blast disease. Pestic. Outlook 12, 23-25. doi: 10.1039/B100803J

Kesavachandran, C. N., Fareed, M., Pathak, M. K., Bihari, V., Mathur, N., and Srivastava, A. K. (2009). "Adverse health effects of pesticides in agrarian populations of developing countries," in Reviews of Environmental Contamination and Toxicology, Vol. 200, ed. D. M. Whitacre (New York, NY: Springer), 33-52.

Khalil, M. S., Moubasher, H., and Hasan, F. F. (2014). Biological control of rice blast disease by Streptomyces flavotricini. Res. J. Pharm. Biol. Chem. Sci. 5, 1453-1461.

Khush, G. S. (2005). What it will take to feed 5.0 billion rice consumers in 2030. Plant Mol. Biol. 59, 1-6. doi: 10.1007/s11103-005-2159-5

Kim, B. S., Moon, S. S., and Hwang, B. K. (1999). Isolation, identification, and antifungal activity of a macrolide antibiotic, oligomycin A, produced by Streptomyces libani. Can. J. Bot. 77, 850-858. doi: 10.1139/b99-044

Kino, T., Hatanaka, H., Hashimoto, M., Nishiyama, M., Goto, T., Okuhara, M., et al. (1987). FK-506, a novel immunosuppressant isolated from a Streptomyces. I. fermentation, isolation, and physico-chemical and biological characteristics. J. Antibiot. 40, 1249-1255. doi: 10.7164/antibiotics.40.1256

Komárek, M., Čadková, E., Chrastnı, V., Bordas, F., and Bollinger, J.-C. (2010). Contamination of vineyard soils with fungicides: a review of environmental and toxicological aspects. Environ. Int. 36, 138-151. doi: 10.1016/j.envint.2009. 10.005

Kumar, P. S., Duraipandiyan, V., and Ignacimuthu, S. (2014). Isolation, screening and partial purification of antimicrobial antibiotics from soil Streptomyces sp. SCA 7. Kaohsiung J. Med. Sci. 30, 435-446. doi: 10.1016/j.kjms.2014.05.006

Kwon, J. H., Kim, J., and Kim, W. I. (2011). First report of Rhizopus oryzae as a postharvest pathogen of apple in Korea. Mycobiology 39, 140-142. doi: 10.4489/ MYCO.2011.39.2.140

Kyndt, T., Fernandez, D., and Gheysen, G. (2014). Plant-parasitic nematode infections in rice: molecular and cellular insights. Annu. Rev. Phytopathol. 52, 135-153. doi: 10.1146/annurev-phyto-102313-050111

Laborte, A., Nelson, A., Jagadish, K., Aunario, J., Sparks, A., Ye, C., et al. (2012). Rice feels the heat. Rice Today 11, 30-31.

Lam, K. S. (2006). Discovery of novel metabolites from marine actinomycetes. Curr. Opin. Microbiol. 9, 245-251. doi: 10.1016/j.mib.2006.03.004

Lee, C. H., Kim, B. J., Choi, G. J., Cho, K. Y., Yang, H., Shin, C., et al. (2002). Streptomyces with antifungal activity against rice blast causing fungus, Magnaporthe grisea. J. Microbiol. Biotechnol. 12, 1026-1028.

Lee, L. H., Zainal, N., Azman, A. S., Eng, S. K., Ab Mutalib, N. S., Yin, W. F., et al. (2014a). Streptomyces pluripotens sp. nov., a bacteriocin-producing streptomycete that inhibits meticillin-resistant Staphylococcus aureus. Int. J. Syst. Evol. Microbiol. 64, 3297-3306. doi: 10.1099/ijs.0.065045-0

Lee, L. H., Zainal, N., Azman, A. S., Eng, S. K., Goh, B. H., Yin, W. F., et al. (2014b). Diversity and antimicrobial activities of actinobacteria isolated from tropical mangrove sediments in Malaysia. Sci. World J. 2014, 1-14. doi: 10.1155/2014/ 698178

Li, Q., Jiang, Y., Ning, P., Zheng, L., Huang, J., Li, G., et al. (2011). Suppression of Magnaporthe oryzae by culture filtrates of Streptomyces globisporus JK-1. Biol. Control 58, 139-148. doi: 10.1016/j.biocontrol.2011.04.013

Mahadevan, B., and Crawford, D. L. (1997). Properties of the chitinase of the antifungal biocontrol agent Streptomyces lydicus WYEC108. Enzyme Microb. Technol. 20, 489-493. doi: 10.1016/S0141-0229(96)00175-5

Martínez, J. A. (2012). "Natural fungicides obtained from plants," in Fungicides for Plant and Animal Diseases, eds D. Dhanasekaran, N. Thajuddin, and A. Panneerselvam (Rijeka: InTech Open), 3-28.

Minuto, A., Spadaro, D., Garibaldi, A., and Gullino, M. L. (2006). Control of soilborne pathogens of tomato using a commercial formulation of Streptomyces griseoviridis and solarization. Crop Protect. 25, 468-475. doi: 10.1016/j.cropro. 2005.08.001

Montesinos, E. (2003). Development, registration and commercialization of microbial pesticides for plant protection. Int. Microbiol. 6, 245-252. doi: 10. 1007/s10123-003-0144-x
Muthayya, S., Sugimoto, J. D., Montgomery, S., and Maberly, G. F. (2014). An overview of global rice production, supply, trade, and consumption. Ann N. Y. Acad. Sci. 1324, 7-14. doi: 10.1111/nyas. 12540

Ningthoujam, S., Sanasam, S., Tamreihao, K., and Nimaich, S. (2009). Antagonistic activities of local actinomycete isolates against rice fungal pathogens. Afr. J. Microbiol. Res. 3, 737-742.

Ou, S. H. (1980). A look at worldwide rice blast disease control. Plant Dis. 64, 439-445. doi: 10.1094/PD-64-439

Pal, K. K., and Gardener, B. M. (2006). Biological control of plant pathogens. Plant Health Instructor 2, 1117-1142. doi: 10.1094/PHI- A-2006-1117-02

Palaniyandi, S. A., Yang, S. H., Zhang, L., and Suh, J. W. (2013). Effects of actinobacteria on plant disease suppression and growth promotion. Appl. Microbiol. Biotechnol. 97, 9621-9636. doi: 10.1007/s00253-013-5206-1

Pelaez, F. (2006). The historical delivery of antibiotics from microbial natural products-can history repeat? Biochem. Pharmacol. 71, 981-990. doi: 10.1016/ j.bcp.2005.10.010

Pest Management Regulatory Agency (2003). Proposed Regulatory Decision Document-Mycostop Biofungicide Streptomyces griseoviridis Strain K61 (PRDD2003-07). Available at: http://publications.gc.ca/collections/Collection/ H113-9-2003-7E.pdf (accessed October 20, 2016).

Pimentel, D., Mclaughlin, L., Zepp, A., Lakitan, B., Kraus, T., Kleinman, P., et al. (1991). Environmental and economic effects of reducing pesticide use. BioScience 41, 402-409. doi: 10.1016/0167-8809(93)90030-S

Pooja, K., and Katoch, A. (2014). Past, present and future of rice blast management. Plant Sci. Today 1, 165-173. doi: 10.14719/pst.2014.1.3.24

Prabavathy, V. R., Mathivanan, N., and Murugesan, K. (2006). Control of blast and sheath blight diseases of rice using antifungal metabolites produced by Streptomyces sp. PM5. Biol. Control 39, 313-319. doi: 10.1016/j.biocontrol.2006. 07.011

Ramesh, S., and Mathivanan, N. (2009). Screening of marine actinomycetes isolated from the Bay of Bengal, India for antimicrobial activity and industrial enzymes. World J. Microbiol. Biotechnol. 25, 2103-2111. doi: 10.1007/s11274009-0113-4

Rhee, K. H. (2003). Purification and identification of an antifungal agent from Streptomyces sp. KH-614 antagonistic to rice blast fungus, Pyricularia oryzae. J. Microbiol. Biotechnol. 13, 984-988.

Robertson, J., and Stevens, K. (2014). Pyrrolizidine alkaloids. Natural Prod. Rep. 31, 1721-1788. doi: 10.1039/C4NP00055B

Rothrock, C. S., and Gottlieb, D. (1984). Role of antibiosis in antagonism of Streptomyces hygroscopicus var. geldanus to Rhizoctonia solani in soil. Can. J. Microbiol. 30, 1440-1447. doi: 10.1139/m84-230

Schumacher, R. W., Talmage, S. C., Miller, S. A., Sarris, K. E., Davidson, B. S., and Goldberg, A. (2003). Isolation and structure determination of an antimicrobial ester from a marine sediment-derived bacterium. J. Nat. Prod. 66, 1291-1293. doi: $10.1021 / \mathrm{np} 020594 \mathrm{e}$

Sehgal, S., Baker, H., and Vézina, C. (1975). Rapamycin (AY-22,989), a new antifungal antibiotic. II. Fermentation, isolation and characterization. J. Antibiot. 28, 727-732. doi: 10.7164/antibiotics.28.727

Sehgal, S. N. (1998). Rapamune ${ }^{\circledR}$ (RAPA, rapamycin, sirolimus): mechanism of action immunosuppressive effect results from blockade of signal transduction and inhibition of cell cycle progression. Clin. Biochem. 31, 335-340. doi: 10. 1016/S0009-9120(98)00045-9

Ser, H. L., Ab Mutalib, N. S., Yin, W. F., Chan, K. G., Goh, B. H., and Lee, L. H. (2015a). Evaluation of antioxidative and cytotoxic activities of Streptomyces pluripotens MUSC 137 isolated from mangrove soil in Malaysia. Front. Microbiol. 6: 1398. doi: 10.3389/fmicb.2015.01398

Ser, H. L., Law, J. W. F., Chaiyakunapruk, N., Jacob, S. A., Palanisamy, U. D., Chan, K. G., et al. (2016a). Fermentation conditions that affect clavulanic acid production in Streptomyces clavuligerus: a systematic review. Front. Microbiol. 7: 522. doi: $10.3389 /$ fmicb. 2016.00522

Ser, H. L., Palanisamy, U. D., Yin, W. F., Chan, K. G., Goh, B. H., and Lee, L. H. (2016b). Streptomyces malaysiense sp. nov.: a novel Malaysian mangrove soil actinobacterium with antioxidative activity and cytotoxic potential against human cancer cell lines. Sci. Rep. 6: 24247. doi: 10.1038/srep24247

Ser, H. L., Palanisamy, U. D., Yin, W. F., Malek, S. N. A., Chan, K. G., Goh, B. H., et al. (2015b). Presence of antioxidative agent, Pyrrolo [1, 2-a] pyrazine-1, 4dione, hexahydro-in newly isolated Streptomyces mangrovisoli sp. nov. Front. Microbiol. 6: 854. doi: 10.3389/fmicb.2015.00854 
Ser, H. L., Tan, W. S., Ab Mutalib, N. S., Cheng, H. J., Yin, W. F., Chan, K. G., et al. (2015c). Genome sequence of Streptomyces pluripotens MUSC 135T exhibiting antibacterial and antioxidant activity. Mar. Genomics 24, 281-283. doi: 10.1016/ j.margen.2015.09.010

Ser, H. L., Tan, L. T. H., Palanisamy, U. D., Abd Malek, S. N., Yin, W. F., Chan, K. G., et al. (2016c). Streptomyces antioxidans sp. nov., a novel mangrove soil actinobacterium with antioxidative and neuroprotective potentials. Front. Microbiol. 7: 899. doi: 10.3389/fmicb.2016.00899

Sesma, A., and Osbourn, A. E. (2004). The rice leaf blast pathogen undergoes developmental processes typical of root-infecting fungi. Nature 431, 582-586. doi: $10.1038 /$ nature 02880

Skamnioti, P., and Gurr, S. J. (2009). Against the grain: safeguarding rice from rice blast disease. Trends Biotechnol. 27, 141-150. doi: 10.1016/j.tibtech.2008.12.002

Smith, R., Peterson, W., and Mccoy, E. (1954). Oligomycin, a new antifungal antibiotic. Antibiot. Chemother. 4, 962-970.

Suleman, P., Al-Musallam, A., and Menezes, C. (2002). The effect of biofungicide Mycostop on Ceratocystis radicicola, the causal agent of black scorch on date palm. Biol. Control 47, 207-216. doi: 10.1023/A:1014519726573

Suprapta, D. N. (2012). Potential of microbial antagonists as biocontrol agents against plant fungal pathogens. J ISSAAS 18, 1-8.

Takeuchi, S., Hirayama, K., Ueda, K., Sakai, H., and Yonehara, H. (1958). Blasticidin S, a new antibiotic. J. Antibiot. 11, 1-5.

Tan, L. T. H., Chan, K. G., Lee, L. H., and Goh, B. H. (2016). Streptomyces bacteria as potential probiotics in aquaculture. Front. Microbiol. 7: 79. doi: 10.3389/fmicb. 2016.00079

Tan, L. T. H., Ser, H. L., Yin, W. F., Chan, K. G., Lee, L. H., and Goh, B. H. (2015). Investigation of antioxidative and anticancer potentials of Streptomyces sp. MUM256 isolated from Malaysia mangrove soil. Front. Microbiol. 6:1316. doi: 10.3389/fmicb.2015.01316

Tapadar, S. A., and Jha, D. K. (2013). "Chapter 5 disease management in staple crops: a bacteriological approach," in Bacteria in Agrobiology: Disease Management, ed. D. K. Maheshwari (New York, NY: Springer), 111-152.

Tian, X., Cao, L., Tan, H., Zeng, Q., Jia, Y., Han, W., et al. (2004). Study on the communities of endophytic fungi and endophytic actinomycetes from rice and their antipathogenic activities in vitro. World J. Microbiol. Biotechnol. 20, 303-309. doi: 10.1023/B:WIBI.0000023843. $83692.3 \mathrm{f}$

Trejo-Estrada, S., Paszczynski, A., and Crawford, D. (1998). Antibiotics and enzymes produced by the biocontrol agent Streptomyces violaceusniger YCED-9. J. Ind. Microbiol. Biotechnol. 21, 81-90. doi: 10.1038/sj.jim. 2900549

U. S. Environmental Protection Agency (2005). Biopesticide Registration Action Document-Streptomyces lydicus WYEC 108 (PC Code 006327). Available online at: https://www3.epa.gov/pesticides/chem_search/reg_actions/registration/ decision_PC-006327_15-Feb-05.pdf (accessed October 20, 2016).

Umezawa, H., Okami, Y., Hashimoto, T., Suhara, Y., Mamada, M., and Takeuchi, T. (1965). A new antibiotic, kasugamycin. J. Antibiot. Ser. A. 18, 101-103.

Varma, J., and Dubey, N. (1999). Prospectives of botanical and microbial products as pesticides of tomorrow. Curr. Sci. 76, 172-178.

Vasudevan, P., Kavitha, S., Priyadarisini, V. B., Babujee, L., and Gnanamanickam, S. S. (2002). "Chapter 2: biological control of rice diseases," in Biological Control of Crop Diseases, ed. S. S. Gnanamanickam (New York, NY: Marcel Dekker Inc).

Waksman, S. A., and Henrici, A. T. (1943). The nomenclature and classification of the actinomycetes. J. Bacteriol. 46, 337-341.
Wilson, R. A., and Talbot, N. J. (2009). Under pressure: investigating the biology of plant infection by Magnaporthe oryzae. Nat. Rev. Microbiol. 7, 185-195. doi: $10.1038 /$ nrmicro2032

Wu, G., Culley, D. E., and Zhang, W. (2005). Predicted highly expressed genes in the genomes of Streptomyces coelicolor and Streptomyces avermitilis and the implications for their metabolism. Microbiology 151, 2175-2187. doi: 10.1099/ mic. $0.27833-0$

Xiong, Z. Q., Tu, X. R., Wei, S. J., Huang, L., Li, X. H., Lu, H., et al. (2013). In vitro antifungal activity of antifungalmycin 702, a new polyene macrolide antibiotic, against the rice blast fungus Magnaporthe grisea. Biotechnol. Lett. 35, 1475-1479. doi: 10.1007/s10529-013-1229-z

Yamaguchi, I. (1982). Fungicides for control of rice blast disease. J. Pest. Sci. 7, 307-316. doi: 10.1584/jpestics.7.307

Yang, J. H., Liu, H. X., Zhu, G. M., Pan, Y. L., Xu, L. P., and Guo, J. H. (2008). Diversity analysis of antagonists from rice-associated bacteria and their application in biocontrol of rice diseases. J. Appl. Microbiol. 104, 91-104. doi: 10.1111/j.1365-2672.2007.03534.x

Yang, P., Li, M., Zhao, J., Zhu, M., Shang, H., Li, J., et al. (2010). Oligomycins A and C, major secondary metabolites isolated from the newly isolated strain Streptomyces diastaticus. Folia Microbiol. 55, 10-16. doi: 10.1007/s12223-0100002-0

Yoon, M. Y., Cha, B., and Kim, J. C. (2013). Recent trends in studies on botanical fungicides in agriculture. Plant Pathol. J. 29, 1-9. doi: 10.5423/PPJ.RW.05.2012. 0072

Yoshida, K., Saitoh, H., Fujisawa, S., Kanzaki, H., Matsumura, H., Yoshida, K., et al. (2009). Association genetics reveals three novel avirulence genes from the rice blast fungal pathogen Magnaporthe oryzae. Plant Cell 21, 1573-1591. doi: 10.1105/tpc.109.066324

Zarandi, M. E., Bonjar, G. H. S., and Dehkaei, F. P. (2013). In vitro antagonistic antifungal-activity of Streptomyces isolate 339 against Magnaporthe oryzae. Am. J. Agric. Biol. Sci. 8, 212-216. doi: 10.3844/ajabssp.2013.212.216

Zarandi, M. E., Bonjar, G. S., Dehkaei, F. P., Moosavi, S. A., Farokhi, P. R., and Aghighi, S. (2009). Biological control of rice blast (Magnaporthe oryzae) by use of Streptomyces sindeneusis isolate 263 in greenhouse. Am. J. Appl. Sci. 6, 194-199. doi: 10.3844/ajas.2009.194.199

Zhang, Y. L., Li, S., Jiang, D. H., Kong, L. C., Zhang, P. H., and Xu, J. D. (2013). Antifungal activities of metabolites produced by a termite-associated Streptomyces canus BYB02. J. Agri. Food Chem. 61, 1521-1524. doi: 10.1021/ jf305210u

Zhou, L., Zhang, X., Li, C., Christensen, M. J., and Nan, Z. (2015). Antifungal activity and phytochemical investigation of the asexual endophyte of Epichloë sp. from Festuca sinensis. Sci. China Life Sci. 58, 821-826. doi: 10.1007/s11427015-4845-0

Conflict of Interest Statement: The authors declare that the research was conducted in the absence of any commercial or financial relationships that could be construed as a potential conflict of interest.

Copyright (C) 2017 Law, Ser, Khan, Chuah, Pusparajah, Chan, Goh and Lee. This is an open-access article distributed under the terms of the Creative Commons Attribution License (CC BY). The use, distribution or reproduction in other forums is permitted, provided the original author(s) or licensor are credited and that the original publication in this journal is cited, in accordance with accepted academic practice. No use, distribution or reproduction is permitted which does not comply with these terms. 